DOI: https://doi.org/10.24867/04BE23Pavlovic

\title{
РЕАЛИЗАЦИЈА БЕЖИЧНОГ АКУСТИЧНОГ СЕНЗОРА БАЗИРАНА НА БЛУТУТ ТЕХНОЛОГИЈИ
}

\section{IMPLEMENTATION OF A WIRELESS ACOUSTIC SENSOR BASED ON BLUETOOTH TECHNOLOGY}

\section{Александар-Вук Павловић, Мирослав Поповић, Факултет техничких наука, Нови Сад}

\section{ОбЛасТ - ЕЛЕКТРОТЕХНИКА И РАЧУНАРСТВО}

Кратак садржај - Развој технологије довео је до повећања перформанси и пада иена електронских уређаја, што је проузроковало појаву Интернета Ствари - велики број умрежених уграђених уређаја чија је примена побољшање квалитета живота људи. Ови уређаји се уграђују и у домове, доводећи до појаве паметних кућа. Великом брзином, главна спрега комуникације са уређајима у паметној кући постаје паметни звучник. Уколико је корисник удаљен од уређаја, квалитет комуникаџије опада због деформаџија звука. Претпоставља се да се квалитет комункаџије може побољшати уградњом уређаја са микрофоном унутар просторије. У овом раду је представљена реализащија оваквог уређаја заснована на Блутут технологији. Испитана је потрошња електричне енергије и квалитет везе на различитим удаљеностима и добијени су задовољавајући резултати.

Кључне речи: Звук, Блутут, Бежична комуникација, Микрофон, Сензор

Abstract - Continued development of technology led to an increase in performance and decrease in price of electronic devices, which further led to Internet of Things - a term used to describe a multitude of connected embedded devices designed to improve quality of life. These devices can also be found in homes, giving rise to smart homes. Increasingly, the main communication interface in a smart home is a smart speaker. If the user is further away from the device, the quality of communication suffers due to sound deformation. An assumption is made that the quality of communication can be improved by placing devices that contain a microphone inside a room. This thesis presents an implementation of such a device based on Bluetooth technology. Power consumption and connection quality at different distances were measured and tested and acceptable results were obtained.

Keywords: Sound, Bluetooth, Wireless Communication, Microphone, Sensor

\section{НАПОМЕНА:}

Овај рад проистекао је из мастер рада чији ментор је био проф. др Мирослав Поповић.

\section{1. УВОД}

Развој технологије и електронике довео је до повећања перформанси електронских компонената, смањења њихове физичке величине и пада њихових цена. Ово је проурзоковало настанак нове брзоразвијајуће парадигме - Интернета ствари (енгл. ІоТ). Интернет ствари представља умрежавање уграђених и наменских уређаја у циљу постизања комплекснијих захтева које појединачни уређаји нису у стању да подрже. Често се проналази примена оваквих „ствари“ у виду уређаја потрошачке електронике који имају за циљ побољшање квалитета живота људи. Овакви уређаји се све чешће могу пронаћи у домовима, тј. у тзв. паметним кућама.

Великом брзином, главна спрега комуникације са уређајима у паметној кући постаје такозвани паметни звучник - уређај који је у стању да прима гласовне наредбе од корисника, проследи их у одговарајућем формату другим уређајима и кориснику да повратну информацију, у виду синтетизованог људског гласа [1]. Оваква спрега поседује једну битну ману, а то је да спрега између корисника и уређаја не постоји уколико корисник и уређај нису у могућности да се међусобно чују. У овом раду претпостављамо да се поменути проблем може решити постављањем већег броја уређаја са микрофоном унутар просторије који би били спојени са паметним звучником. Представићемо мотивацију за избором Блутут технологије и $E S P$ развојне плоче, идеају и реализацију алгоритма за управљање поменутим уређајима и резултате испитивања карактеристика решења.

\section{2. МОТИВАЦИЈА И РЕАЛИЗАЦИЈА}

Beћ je поменуто да је битна мана гласовне комуникације са паметним звучником постојање ситуација у којој корисник и уређај нису у могућности да се међусобно чују. Удаљеност (када се микрофон паметног звучника налази у удаљеном пољу у односу на извор звука, тј, корисника), бука, акустичне карактеристике просторије и други фактори који се одликују разноврсним звучним деформацијама имају велики утицај на квалитет спреге. Претпоставили смо да се овај проблем може ублажити или решити постављањем већег броја јефтиних нископотрошних уређаја опремљених микрофоном унутар једне и/или више просторија. Коришћењем алгоритма за избор, микрофон на 
најбољој позицији да чује корисника (микрофон који ce налази у блиском пољу корисника) би био постављен као активан и звучни сигнал би од њега био пренет до паметног звучника. Пратећи ову претпоставку и ослањајући се на нека претходна истраживања [2] [3], осмислили смо поменути алгоритам и одлучили се да га имплементирамо на ESP развојној плочи, ослањајући се на Блутут технологију за пренос команди и звучног сигнала. Избор ESP развојне плоче је био мотивисан њеном великом доступношћу, постојањем интегрисаног Блутут контролера и малом ценом, док је избор Блутут технологије био мотивисан поузданошћу преноса и ниском потрошњом електричне енергије.

Алгоритам смо реализовали кроз клијент-послужилац архитектуру са већим бројем послужилаца и једним клијентом. Сваки извор звука представља један послужилац, док пријемник представља клијента.

Сваки послужилац се понаша на идентичан начин, тако што се прво учини видљивим другим Блутут уређајима, а затим чека захтеве од стране клијента. Ако добије захтев од клијента, повезује се са њим коришћењем Блутут технологије и шаље вредности звучног сигнала на клијента.

Клијент се понаша тако што прво претражи све видљиве Блутут уређаје и формира листу свих доступних послужилаца. Уколико у задатом временском интервалу није пронашао ниједног послужиоца, наставља претрагу. Након завршетка тражења, клијент се повезује са послужиоцем коришћењем Блутут технологије и са њега преузима вредности звучног сигнала уколико послужилац назначи да корисник тренутно издаје говорну наредбу. Када клијент закључи да је корисник престао да издаје наредбу, престаје да преузима вредности звучног сигнала и поново почиње да проверава код свих послужилаца да ли је корисник кренуо да издаје говорну наредбу. Овај процес се понавља непрестано.

Фокус овог рада је био на испитивању квалитета Блутут везе између послужиоца и клијента и испитивању потрошње електричне енергије. С тим на уму, уместо реалних гласовних наредби од стране корисника, користили смо апстрактнији вид активирања преноса између послужиоца и клијента псеудонасумичне бројеве који су били интерпретирани као ознака која је клијента упућивала да ли да преузима звучни садржај са послужиоца или не. Ово је олакшало испитивање послужиоца и клијента.

Алгоритам смо имплементирали за Xtensa LX6 архитектуру, која долази као саставни део ESP интегрисаног микроконтролера. Производи се од стране већег броја компанија, а у овом раду је коришћена развојна плоча ESP32 Devkit V1, приказана на слици 1. Ова развојна плоча се одликује двојезгарним процесором Xtensa LX6, радног такта до $240 \mathrm{MHz}$, радном $S R A M$ меморијом величине $520 \mathrm{KiB}$ и уграђеним Блутут контролером који подржава Блутут верзију 4.2. Ова развојна плоча се одликује и ниском ценом, која је у тренутку писања овог рада била мања од 7 америчких долара.

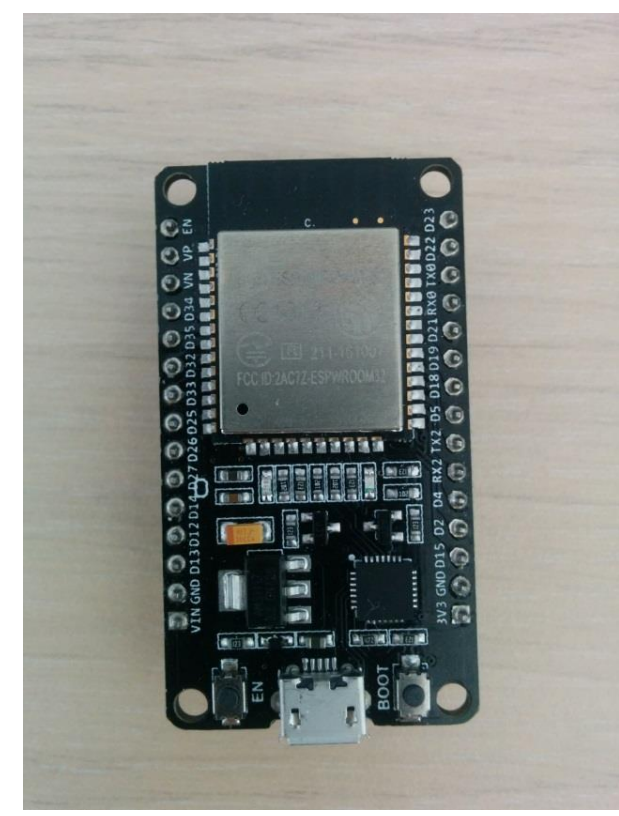

Слика 1: Изглед ESP DevKit v1 развојне плоче

$\mathrm{Ca}$ стране програмске подршке, коришћено је Espressif IDF програмско окружење, које се може слободно преузети са Интернета и састоји се од преводиоца, стандардне библиотеке, библиотека за уграђене компоненте (од највећег значаја је наравно библиотека за управљање Блутут везом и пакетима на физичком нивоу), система за аутоматско превођење са зависностима, документације и др. Преводилац је заснован на познатом FLOSS GCC преводиоцу, што је умногоме олакшало писање програмске подршке, због претходног искуства које смо имали са овим преводиоцем.

Одређени проблем при реализацији настао је због архитектуре библиотеке за Блутут подршку. Функције из ове библиотеке обављају своје задатке асинхроно и користе повратне функције као начин сигнализације да је задатак (успешно или неуспшено) завршен. Због овакве архитектуре, одређене функције унутар кода клијента нисмо могли да имплементирамо линеарно, па смо их имплементирали коришћењем аутомата са коначним бројем стања. Сам аутомат је описан функцијом, док су стања представљена вредностима енумерације, а прелази се иницирају на основу горепоменутих повратних функција. Целокупан код решења се може пронаћи на Интернету, на следећим адресама:

- Послужилац на http://github.com/authext/bt_server

- Клијент на http://github.com/authext/bt_client

Целокупан код је лиценциран под BSD-3 лиценцом.

\section{3. РЕЗУЛТАТИ}

Две одлике које су биле у фокусу овог рада су потрошња електричне енергије и квалитет везе, који се огледа у односу послатих и примљених Блутут пакета. Вредности ових параметара су мерене засебно.

За мерење потрошње електричне енергије, коришћен је мерни уређај Gembird EG-EMU-03 USB power meter, 
који је приказан на слици 2. Овај уређај приказује неколико параметера везаних за електричне одлике испитиваног уређаја, од којих су најважније утрошена електрична енергија (на уређају изражена у $W h$ ) и протекло време од почетка мерења (на уређају изражено у часовима, минутама и секундама), на основу којих се може израчунати просечна снага мереног уређаја. На мерном уређају се, осим поменутих одлика, могу уочити и тренутни интензитет струје (изражен у $A$ ), тренутни напон (изражен у $V$ ), количина пренесеног наелектрисања (изражена у $m A h$ ) и тренутна снага (изражена у $W$ ). Мерни уређај је декларисан са резолуцијом очитавања напона од $10 \mathrm{mV}$, резолуцијом очитавања струје од $1 m A$ и резолуцијом очитавања времена од $1 s$. Мерење смо вршили у неколико независних конфигурација:

- Послужилац који није повезан са клијентом,

- Послужилац спојен са клијентом коришћењем Блутут технологије

- Клијент спојен са послужиоцем коришћењем Блутут технологије

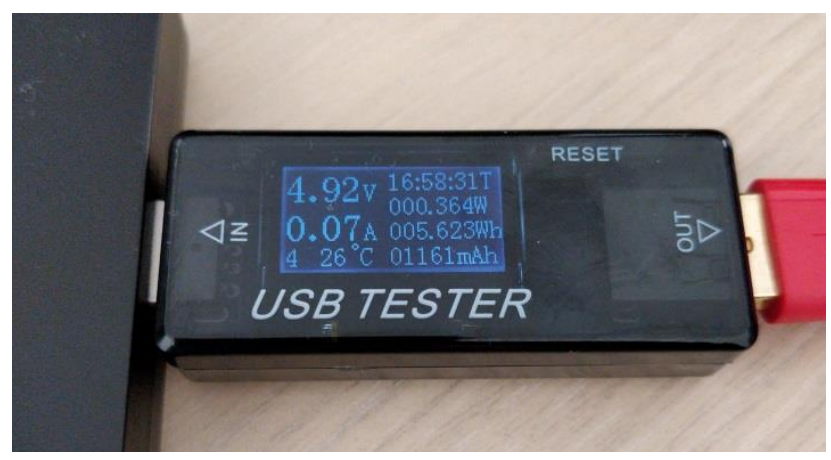

Слика 2: Gembird EG-EMU-03 USB power mеter мерни уређаj

Да бисмо извршили само мерење, ESP уређај смо повезали на мерни уређај (тестер). Након тога, тестер смо прикључили на USB порт рачунара. Тестер је искључиво електрични уређај и што се тиче USB протокола у потпуности је транспарентан. Рачунар овако повезан склоп препознаје као ESP уређај, на исти начин као и када тестер није повезан. Преко рачунара смо на ESP уређају покренули жељени програм (послужилац или клијент). Уколико је потребно, на другим ESP уређајима смо покренули програм (клијент или послужилац) неопходан да се оствари комуникација описана конфигурацијом. Сваку конфигурацију смо пустили да ради одређену количину времена, након чега смо измерили утрошену електричну енергију и израчунали просечну снагу. Резултати се могу видети у табелама 1, 2 и 3.

ТАБЕЛА 1: Приказ потрошње електричне енергије послужиоца који није повезан са клијентом

\begin{tabular}{|c|c|c|}
\hline $\begin{array}{c}\text { Tрајање } \\
(\text { min })\end{array}$ & $\begin{array}{c}\text { Утрошена Енергија } \\
(W h)\end{array}$ & $\begin{array}{c}\text { Просечна снага } \\
(W)\end{array}$ \\
\hline 80 & 0.420 & 0.315 \\
\hline 81 & 0.434 & 0.317 \\
\hline 89 & 0.472 & 0.318 \\
\hline
\end{tabular}

ТАБЕЛА 2: Приказ потрошње електричне енергије послужиоца који је повезан са клијентом

\begin{tabular}{|c|c|c|}
\hline $\begin{array}{c}\text { Tрајање } \\
(\text { min })\end{array}$ & $\begin{array}{c}\text { Утрошена Енергија } \\
(W h)\end{array}$ & $\begin{array}{c}\text { Просечна снага } \\
(W)\end{array}$ \\
\hline 62 & 0.407 & 0.393 \\
\hline 99 & 0.648 & 0.393 \\
\hline 1028 & 6.760 & 0.394 \\
\hline
\end{tabular}

ТАБЕЛА 3: Приказ потрошње електричне енергије клијента који је повезан са послужиоцем

\begin{tabular}{|l|r|ll|}
\hline Tрајање $(\mathrm{min})$ & $\begin{array}{l}\text { Утрошена } \\
\text { Енергија }(W h)\end{array}$ & $\begin{array}{l}\text { Просечна } \\
(W)\end{array}$ & снага \\
\hline 62 & 0.345 & 0.333 \\
\hline 100 & 0.549 & 0.329 \\
\hline 1030 & 5.686 & & 0.331 \\
\hline
\end{tabular}

На основу измерених резултата и тренутне цене електричне енергије [4], израчунате су цене годишње потрошње електричне енергије у најгорем случају (једнотарифни обрачун, црвена зона, уређај ради непрекидно целу годину) и представљене у табели 4.

ТАБЕЛА 4: Годишња цена за непрестано коришћење уређаја у црвеној зони, при једнотарифном обрачуну

\begin{tabular}{|l|r|l|}
\hline Програм & Снага $(W)$ & $\begin{array}{l}\text { Цена } \\
(R S D / \text { година })\end{array}$ \\
\hline Послужилац & 0.394 & 50.812 \\
\hline Клијент & 0.333 & 42.945 \\
\hline
\end{tabular}

Друга битна одлика која је мерена је квалитет везе. Вредности звучног сигнала се шаљу путем Блутут пакета. Лако се закључује да ако одређени Блутут пакет који је послат са послужиоца не буде примљен на клијенту да то негативно утиче на квалитет везе.

Што више пакета буде изгубљено на путу до клијента, то ће квалитет везе више трпети, што се огледа у разним деформацијама звучног сигнала који се реконструише на клијенту. Број изгубљених пакета се рачуна као разлика послатих пакета на послужиоцу и примљених пакета на клијенту.

Извршено је мерење послатих и примљених пакета. Блутут веза између послужиоца и клијента је била прекидана и поново успостављана, на сваких $20 s$. Коришћене су следеће конфигурације:

- Послужилац и клијент су постављени на мање од $10 \mathrm{~cm}$.

- Послужилац и клијент су постављени на даљину од $270 \mathrm{~cm}$, са различитих страна зида.

- Послужилац и клијент су постављени на даљину од $690 \mathrm{~cm}$, са различитих страна зида.

Резултати мерења приказани су у табелама 5, 6 и 7. 
ТАБЕЛА 5: Резултати мерења где су послужилац и клијент постављени на даљину о $210 \mathrm{~cm}$

\begin{tabular}{|r|r|l|l|}
\hline $\begin{array}{l}\text { Послатих } \\
\text { пакета }\end{array}$ & $\begin{array}{l}\text { Примљених } \\
\text { пакета }\end{array}$ & $\begin{array}{l}\text { Изгубљених } \\
\text { пакета }\end{array}$ & $\begin{array}{l}\text { Проценат } \\
\text { изгубљених }\end{array}$ \\
\hline 119986 & 119981 & 5 & 0.004 \\
\hline 120098 & 120094 & 4 & 0.003 \\
\hline 120220 & 120212 & 8 & 0.007 \\
\hline
\end{tabular}

Табела 6: Резултати мерења где су послужилац и клијент постављени на даљину од $270 \mathrm{~cm}$

\begin{tabular}{|r|r|r|l|}
\hline $\begin{array}{l}\text { Послатих } \\
\text { пакета }\end{array}$ & $\begin{array}{l}\text { Примљених } \\
\text { пакета }\end{array}$ & $\begin{array}{l}\text { Изгубљених } \\
\text { пакета }\end{array}$ & $\begin{array}{l}\text { Проценат } \\
\text { изгубљених }\end{array}$ \\
\hline 119861 & 119842 & 19 & 0.016 \\
\hline 119553 & 119531 & 22 & 0.018 \\
\hline 119570 & 119562 & 8 & 0.007 \\
\hline
\end{tabular}

ТАБЕЛА 7: Резултати мерења где су послужилац и клијент постављени на даљину од $690 \mathrm{~cm}$

\begin{tabular}{|r|r|r|r|}
\hline $\begin{array}{l}\text { Послатих } \\
\text { пакета }\end{array}$ & $\begin{array}{l}\text { Примљених } \\
\text { пакета }\end{array}$ & $\begin{array}{l}\text { Изгубљених } \\
\text { пакета }\end{array}$ & $\begin{array}{l}\text { Проценат } \\
\text { изгубљених }\end{array}$ \\
\hline 105320 & 105027 & 293 & 0.278 \\
\hline 108227 & 108013 & 214 & 0.197 \\
\hline 114812 & 114421 & 391 & 0.341 \\
\hline
\end{tabular}

\section{4. ЗАКЉУЧАК}

Током израде овог рада, реализовали смо алгоритам за управљање већим бројем уређаја опремљених микрофоном, са циљем решавања проблема који настају при интерпретацији звучног сигнала који је снимљен из удаљеног поља. Овај алгоритам је реализован на јефтиној $E S P$ развојној плочи. Алгоритам подразумева да постоји један клијентски уређај и већи број уређаја послужилаца. Алгоритам уређује начин на који се клијентски уређај повезује на одређени послужилац и са њега преузима вредности звучног сигнала у реалном времену. Након имплементације алгоритма, извршено је мерење потрошње електричне енергије и рачунање цене коришћења оваквог уређаја током дужег временског периода. Такође, извршено је и мерење квалитета везе између клијентског и уређаја послужиоца.

На основу резултата добијених мерењем потрошње електричне енергије и рачунањем годишње цене, долази се до закључка да уколико би корисник користио 10 оваквих уређаја (1 клијент, 9 послужилаца) непрестано током целе године, морао би у најгорем случају да плати нешто више од 500RSD годишње или нешто више од 40RSD месечно.

На основу ових података, закључује се да је овако реализован уређај задовољавајуће јефтин за коришћење.
На основу резултата добијених мерењем квалитета везе примећује се да је проценат изгубљених пакета мањи од $0.5 \%$, што не представља проблем за алгоритам прикривања губитка пакета $S B C$ кодека [5] [6]. Закључује се да овако реализован уређај поседује задовољавајући квалитет преноса звучних података.

\section{5. ЛИТЕРАТУРА}

[1] Н. Рајић, Н. Четић, М. Поповић, С. Танацковић, „Систем за испитивање гласовних команди у паметној кући“ на 62. конференција за електронику, телекомуникације, рачунарство, аутоматику и нуклеарну технику ЕТРАН, 2018.

[2] Д. Додер, Н. Четић, Ј. Ковачевић, М. Поповић, ,Implementation of low cost wireless acoustic sensor based on ESP8266 module“ (енгл) на 2nd International Conference on Eletrical, Eletronic and Computing Engineering, 2016.

[3] Д. Додер, Н. Четић, М. Поповић, Ј. Ковачевић, „Realisation of server application for acoustic sensors based on RTSP, RTP protocols“ (енгл) на 23. Телекомуникациони форум ТЕЛФОР, 2015.

[4] Електропривреда Србије, „Методологија за одређивање цене електричне енергије за јавно снабдевање“, Службени гласник Републике Србије 84/14, 2014, ISSN 0353-8389

[5] C. Hoene, M. Hyder, „Optimally Using the Bluetooth Subband Codec", на The 35th Annual IEEE Conference on Local Computer Networks, 2010.

[6] C. Hoene, M. Hyder, „Considering Bluetooth's Subband Codec (SBC) for Wideband Speech and Audio on the Internet", Технички извештај WSI2009-3, 2009, ISSN 0946-3852

\section{Кратка биографија:}

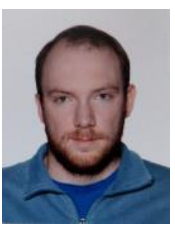

Александар-Вук Павловић рођен је у Новом Саду 1994. године. Дипломски рад на Факултету техничких наука из области Електротехнике и рачунарства Рачунарство и аутоматика одбранио је 2017. године.

контакт: wolf.srb.ns@hotmail.com

Др Мирослав Поповић је редовни професор на Факултету техничких наука (катедра за рачунарску технику и међурачунарске комуникације). Докторирао је на Факултету техничких наука 1990. године. Ужа научна област му је рачунарска техника и рачунарске комуникације. 